\section{Micro-CT Evaluation of Non- instrumented Canal Areas with Different Enlargements Performed by NiTi Systems}

Gustavo De-Deus ${ }^{1}$, Felipe Gonçalves Belladonna² Emmanuel João Nogueira Leal Silva ${ }^{1}$, Juliana Roter Marins ${ }^{1}$, Erick Miranda Souza ${ }^{3}$, Renata Perez ${ }^{1}$, Ricardo Tadeu Lopes ${ }^{4}$, Marco Aurélio Versiani ${ }^{5}$, Sidnei Paciornik ${ }^{6}$, Aline de Almeida Neves ${ }^{7}$

The aim of this study was to compare the percentage of non-instrumented area of root canals prepared with different enlargements using single-file reciprocating systems (Reciproc and WaveOne) and a conventional multi-file rotary (BioRaCe) system by microcomputed tomographic analysis. Thirty mesial roots of mandibular molars with moderate curvature $\left(10^{\circ}\right.$ to $\left.20^{\circ}\right)$ presenting a type II Vertucci canal configuration and similar internal volume were chosen and scanned at an isotropic resolution of $14.16 \mu \mathrm{m}$. The sample was assigned to 3 groups $(n=10)$ according to the system used for root canal preparation: Reciproc, WaveOne, and BioRaCe groups. Second and third scans were taken after the canals were prepared with instruments sizes 25 and 40, respectively. The recorded images of the surface area voxels of the canals, before and after preparation were examined from the furcation level to the apex to quantify the non-instrumented surface. Statistical data were compared using GLM for repeated-measures with a significance level set at $5 \%$. Instrumentation systems did not influence the percentage of untouched root canal surfaces $(p=0.690)$ whilst a significant reduction in the percentage of static voxels was observed after the enlargement of the root canal $(p=0.010)$ in all groups $(p=0.507)$. None of the systems was able to prepare the entire surface area of the mesial root canal of mandibular molars. The increased final apical size resulted in a significant positive effect on the shaping ability of the tested systems.
'Department of Endodontics, UNIGRANRIO - Universidade Grande Rio, Duque de Caxias, RJ, Brazil ${ }^{2}$ Department of Endodontics, UFF - Universidade Federal Fluminense, Niterói, RJ, Brazil ${ }^{3}$ Department of Dentistry 11 , UFMA - Universidade Federal do Maranhão, São Luiz, MA, Brazil ${ }^{4}$ Nuclear Engineering Program, UFRJ - Universidade Federal do Rio de Janeiro, Rio de Janeiro, RJ, Brazil ${ }^{5}$ Department of Restorative Dentistry, School of Dentistry of Ribeirão Preto, USP - Universidade de São Paulo, Ribeirão Preto, SP, Brazil ${ }^{6}$ Department of Material Engineering, PUC-R10 - Pontifícia Universidade Católica do Rio de Janeiro, Rio de Janeiro, RJ, Brazil ${ }^{7}$ Department of Pediatric Dentistry and Orthodontics, UFRJ -

Universidade Federal do Rio de Janeiro, Rio de Janeiro, RJ, Brazil

Correspondence: Dr. Felipe Gonçalves Belladonna, Rua Otávio Carneiro 64/703, lcaraí, 24230-191 Niterói, RJ, Brasil. Tel: +55-21-2621-8794. e-mail: felipebelladonna@hotmail.com

Key Words: shaping ability, micro-CT, non-instrumented canal areas, reciprocation motion, rotary motion.

\section{Introduction}

The recent market introduction of reciprocating nickeltitanium (NiTi) single file-based systems has raised new perspectives on the mechanical preparation of root canal space $(1,2)$. The concept of using a single instrument to prepare the entire root canal is interesting because it is cost-saving compared to the multi-file rotary systems and the learning curve is considerably reduced due to the simplification of the technical procedures (1). Additionally, in the Reciproc system (VDW, Munich, Germany), the R25 instrument does not necessarily require the creation of a smooth and predictable glide path for most cases (3).

Recent studies have reported that single-file reciprocating systems outperformed conventional continuous rotary NiTi preparation (4-8). However, while the shaping ability of the reciprocating systems was proven to be adequate (4-8), some doubts came up with respect to the amount of dentinal chips, irrigants, remaining pulp tissue, bacteria and their by-products that may be extruded into the periradicular tissues as a result of the root canal treatment $(1,4,9,10)$. Additionally, there is a concern that this type of preparation, in which a substantial amount of dentine is removed in a short period of time using a single, large-tapered, and fast-cutting reciprocating instrument, produces a less efficient mechanical debridement than multi-file rotary systems, which consist in a slower, smoother and gradual enlargement of the root canal space (1).

Improvements of imaging software brought clear advances for using micro-computed tomography (micro$\mathrm{CT}$ ) in the endodontic research field (11). This non-invasive scientific tool allows visualization of morphological characteristics of the tooth in a detailed and accurate manner (12-15). Moreover, micro-CT imaging technology has been also used to evaluate the shaping ability of current instruments and techniques (6-8,16-18). Essentially, "shaping ability" refers to the dentinal surface area that is mechanically removed during the canal preparation procedures and may be regarded as a suitable outcome parameter to compare different instrumentation techniques. In general, micro-CT results revealed that more than half of the dentinal walls (ranging from 59.6\% to $79.9 \%$ ) remained unprepared in oval-shaped canals, regardless of the instrumentation technique $(7,16,17)$. Thus, 
for a reciprocating-based single file instrumentation to be considered as an alternative to multi-file rotary systems, it must be able to prepare similar amount of the canal surface area.

Based on the above-mentioned background, the purpose of this study was to compare the percentage of non-instrumented area of root canals prepared with different enlargements using single-file reciprocating systems (Reciproc and WaveOne [Dentsply Maillefer, Baillagues, Switzerland]) and a conventional multi-file rotary (BioRaCe [FKG Dentaire, La-Chaux-de-Fonds, Switzerland]) system using micro-CT analysis. The null hypotheses tested were that: (i) The single-file reciprocating systems and the multi-file rotary system have similar shaping abilities; (ii) Single-file reciprocating systems have similar shaping ability among themselves; (iii) Larger apical preparation does not improve the shaping ability of reciprocating and rotary systems.

\section{Material and Methods}

\section{Sample Size Calculation}

Repeated measures ANOVA within-between interactions was selected from the $\mathrm{F}$ tests family in $\mathrm{G}^{*}$ Power 3.1.7 software (Heinrich Heine Universität, Düsseldorf, Germany). An effect size estimation of 0.3 was determined using previously reported data (18). In that study, the authors calculated the percentage of static voxels between root canals prepared with GT (apical size 20; Dentsply Tulsa Dental, Tulsa, OK, USA) and Profile (apical size 40; Dentsply Maillefer) rotary systems. Alpha-type error of 0.05 , power beta of 0.95 , correlation among repeated measures of 0.7 , non-sphericity correction of 1 , number of groups (within subjects) of 2, and number of measurements (between subjects) of 3 were also specified. Based on these parameters, 20 teeth was the total sample size required for detecting statistically significant differences.

\section{Sample Selection}

This study was revised and approved by the Ethics Committee, Nucleus of Collective Health Studies (Protocol $n^{\circ} 2283$ - CEP/HUPE). Three hundred extracted mandibular first molars selected from a pool of stored extracted teeth were radiographed in buccolingual direction. The angle of curvature of the mesial root was calculated (19) using AxioVision v.4.5 software (Carl Zeiss Vision GmbH, Hallbergmoos, Germany). Only roots with curvature ranging from $10^{\circ}$ to $20^{\circ}$ (moderate curvature) were chosen. In addition, the inclusion criteria comprised only molars in which the final apical gauging of the mesial canals allowed an ISO size $10 \mathrm{~K}$-file (Dentsply Maillefer) to be placed up to the working length (WL). The coronal portions and distal roots of all teeth were removed by using a low-speed saw
(Isomet; Buehler Ltd, Lake Bluff, IL, USA) with water cooling, leaving mesial roots with approximately $12 \pm 1 \mathrm{~mm}$ long to prevent the introduction of confounding variables. As a result, 134 specimens were selected and stored in $0.1 \%$ thymol solution at $5{ }^{\circ} \mathrm{C}$.

To attain an overall outline of the canal anatomy, the mesial roots were pre-scanned in a relatively low isotropic resolution $(70 \mu \mathrm{m})$ using a micro-CT scanner (SkyScan 1173; Bruker microCT, Kontich, Belgium) at $70 \mathrm{kV}$ and 114 $\mathrm{mA}$. Based on the 3 -dimensional models of the root canal achieved from these prescan set of images, 30 specimens with a type II Vertucci canal configuration (two canals with two orifices leaving the pulp chamber but joining short of the apex to form one canal) (20) were chosen.

\section{Micro-CT Scanning Procedures and Reconstruction}

For the experimental procedure, the apex of the mesial root of each tooth was sealed with hot glue, embedded into a thin film of polyvinyl siloxane and then placed coronalapically inside a custom-made epoxy resin holder (Ø 18 $\mathrm{mm}$ ) which was adapted into a sample-holder of a high energy micro-CT device (SkyScan 1173). Each scanning procedure was performed at $70 \mathrm{kV}$ and $114 \mathrm{~mA}$ with an isotropic resolution of $14.16 \mu \mathrm{m}$. A $1 \mathrm{~mm}$-thick aluminium filter was used to reduce artefacts and each projection was acquired in $250 \mathrm{~ms}$, each $0.5^{\circ}$ step through $360^{\circ}$ rotation. Frame averaging of 5 and random movements of 20 were also applied at the acquisition phase to increase signalto-noise ratio and reduce ring artifacts.

The acquired projection images were reconstructed into cross-section slices using proprietary software (NRecon v.1.6.9; Bruker micro-CT) with standardized parameters for beam hardening $(40 \%)$, ring artifact correction of 10 , as well as minimum and maximum contrast limits. The volume of interest was chosen extending from the furcation level to the apex of the root

After that, the specimens were randomly assigned (http://www.random.org) into 3 experimental groups $(n=10)$, according to the system used for root canal preparation: Reciproc, WaveOne and BioRaCe groups. After checking data normality ( $p>0.05$; Shapiro-Wilk test), the degree of homogeneity within the groups with respect to the root length, degree of curvature of the mesial root and initial volume of the canals was statistically confirmed (one-way ANOVA, p>0.05).

\section{Root Canal Preparation}

Root canals were accessed and patency was confirmed by inserting a size $10 \mathrm{~K}$-file through the apical foramen before and after completion of root canal preparation. For all groups, a glide path was created by scouting a stainless steel size $15 \mathrm{~K}$-file (Dentsply Maillefer) up to the WL, which 
was established at $1 \mathrm{~mm}$ from canal length. In each group, instruments were driven with the VDW Silver motor (VDW $\mathrm{GmbH}$ ), according to each manufacturer's instructions. A single experienced operator performed all preparations.

In the Reciproc group, Reciproc R25 (25/0.08) file was introduced into the canal until resistance was felt and then activated in reciprocating motion. The instrument was moved in apical direction using an in-and-out pecking motion of about $3 \mathrm{~mm}$ amplitude with a light apical pressure. After three pecking motions, the instrument was removed from the canal and its flutes were cleaned off. This procedure was performed until the instrument reached the WL. Afterwards, Reciproc R40 (40/0.06) instrument was used with the same protocol. The WaveOne group was prepared with WaveOne Primary (25/0.08) and Large (40/0.08) instruments to the WL using the protocol described for the Reciproc group. In the BioRaCe group, preparation was performed in a crown-down manner with the BioRaCe system using the following sequence: BR0 (25/0.08), BR1 (15/0.05), BR2 (25/0.04), BR3 (25/0.06), BR4 (35/0.04) and BR5 (40/0.04) instruments. The motor was adjusted to 500-600 rpm and $1 \mathrm{~N} / \mathrm{cm}^{2}$. After three steady strokes, the instrument was removed from the canal and cleaned. This $\therefore$ procedure was repeated until the WL was reached.

Between each preparation step, root canals were irrigated with $2 \mathrm{~mL}$ of $5.25 \% \mathrm{NaOCl}$ for 1 min delivered by a VATEA peristaltic pump (ReDent-Nova, Ra'anana, Israel) at a $2 \mathrm{~mL} / \mathrm{min}$ rate, connected to a 30-gauge Endo-Eze Tip (Ultradent Products Inc., South Jordan, UT, USA) inserted up to $2 \mathrm{~mm}$ from the apical foramen. Aspiration was performed with a SurgiTip (Ultradent Products Inc.) attached to a high-speed suction pump. After canal preparation, an additional rinse with $20 \mathrm{~mL}$ of $\mathrm{NaOCl}$ was performed for $10 \mathrm{~min}$. Hence, a total volume of $40 \mathrm{~mL}$ of irrigant was used per canal in a total time of $30 \mathrm{~min}$. A final rinse with $5 \mathrm{~mL} 17 \%$ EDTA $(\mathrm{pH}=7.7)$, delivered at a $1 \mathrm{~mL} / \mathrm{min}$ rate for $3 \mathrm{~min}$, followed by a 5 -minute $5-\mathrm{mL}$ rinse with bi-distilled water was performed. Then the canals were dried with absorbent paper points (Dentsply Maillefer).

Two postoperative micro-CT scans of each specimen after canal preparation with instruments R25 and R40 in the Reciproc group, WaveOne Primary and Large in the WaveOne group, and BR3 and BR5 in the BioRaCe group were performed using the aforementioned parameters.

\section{Image Processing and Analysis}

After reconstruction, pre- and post-operative canal stacks (apical diameters 25 and 40) were registered using a semi-automatic rigid registration plugin implemented in the FIJ software interface. The optimization steps of the rigid registration algorithm were repeated until image stacks did not differ by more than 0.4 tolerance. Multi-resolution registration was used to optimize registration efficiency. All micro-CT data sets were registered without any prior image processing procedure and were examined from the furcation level to the apex to evaluate the amount of noninstrumented surface area. In short, after an automatic threshold to segment pre- and post-operative root canal spaces (minimum threshold algorithm), non-instrumented dentin surface was calculated by subtracting the prepared canal from the original canal. From the resulting image stack (static voxels), the surface area was calculated. The percentage of non-instrumented area was calculated in relation to the sound canal area (total number of surface voxels) by dividing the number of static surface voxels by the total number of surface voxels (21), as described by the formula:

number of static voxels $\times 100$

total number of surface voxels

All image analysis procedures were made using an open-source image analysis program (Fiji v.1.47n; Fiji, Madison, WI, USA).

\section{Statistical Analysis}

Normal distribution of the data was confirmed (ShapiroWill test, $p>0.05$ ) and GLM for repeated-measures (SPSS for Windows v17.0; SPSS Inc., Chicago, IL, USA) was chosen for the analysis, considering the dependent nature of the study design. Apical preparation sizes were tested as the withinsubjects effect while instrumentation systems were set as between-subjects effect. Significance was set at $\alpha=5 \%$.

\section{Results}

Figure 1 displays the percentage of static voxels observed in each group and different apical file diameters.

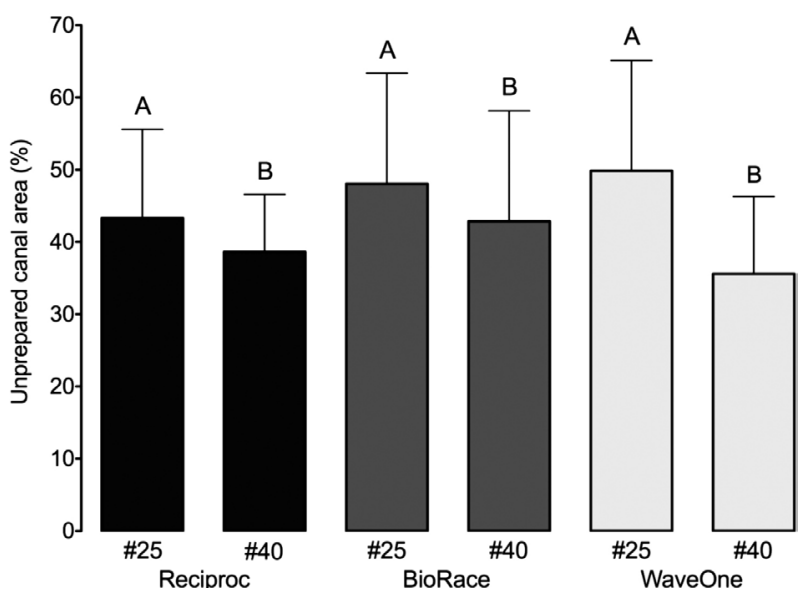

Figure 1. Amount of non-instrumented surface canal areas (\%) of each experimental group. Bar graph shows the average and standard deviation data. Different letters mean statistically significant differences. 
Instrumentation systems did not influence the percentage of untouched root canal surfaces $(p=0.690)$ whilst a significant reduction in the percentage of static voxels was observed after the enlargement of the root canal $(p=0.010)$ in all groups ( $p^{*}$ interaction $=0.507$ ). Figure 2 displays three-dimensional volumetric renderings of representative specimens in each group before and after instrumentation with different apical size diameters.

\section{Discussion}

The main finding of the present study pointed out a similar shaping ability between the reciprocating systems (Reciproc and WaveOne) and the conventional multi-file rotary system (BioRaCe) regarding the percentage of noninstrumented areas of mesial root canals of mandibular molars; therefore, the first hypothesis tested was accepted. This finding is in accordance with previous studies $(4,5,7)$. Thus, even in a more challenging canal anatomy, such as mesial roots of mandibular molars, reciprocating systems displayed a comparable shaping ability to the conventional systems, which is an important aspect as a single-file approach involves less procedural steps and a shorter learning curve.

The second result of the present study stands for the similar shaping ability between the tested single-file reciprocating systems; thus, the second hypothesis was also confirmed. It would be reasonable to assume that the larger the taper the higher the amount of prepared surface area of the root canal walls. However, this was not confirmed by the current results, in which both reciprocating systems have larger tapers (0.06 and 0.08) than the multi-file rotary system (0.04 and 0.06$)$; this agrees with a previous study (18). All together, these findings indicate that the taper size may not be critical for the motor-driven NiTi systems regarding the amount of prepared surface area of the canal walls.

The similar shaping ability of Reciproc and WaveOne was also unexpected, as the latter has larger core and taper and a different cross-section. These characteristics would indicate less flexibility (22) and should have influenced

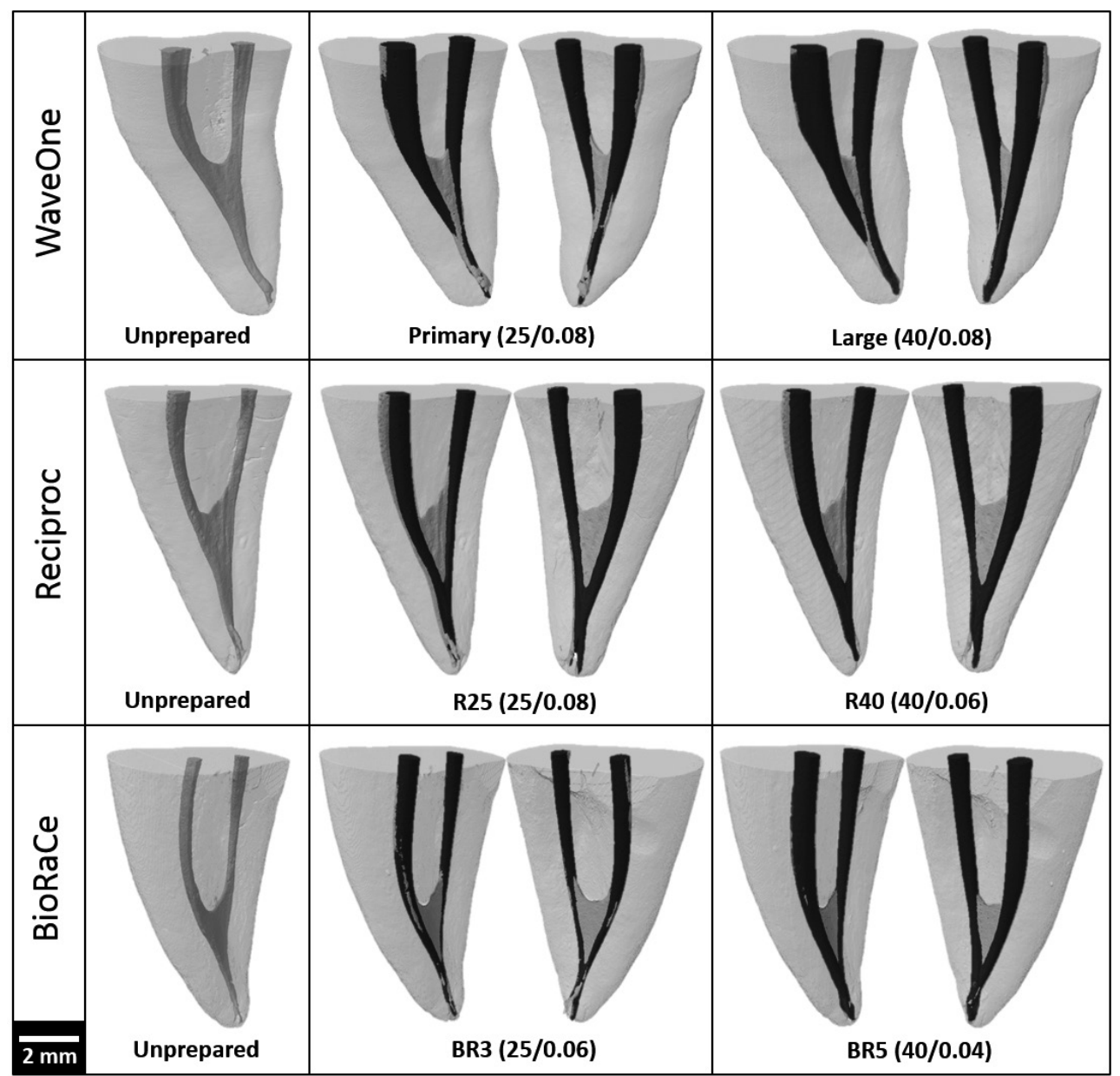

Figure 2. Representative 3D reconstructions of the external and internal anatomy of mesial roots of mandibular molars from each experimental group, before and after root canal preparation. Changes in overall canal shape are visible in the superimposed root canals before (gray) and after (black) step-wise mechanical preparation. 
the shaping ability in curved canals as those used in the present study. In spite of marked differences in the overall design, Reciproc and WaveOne instruments also have important common features such as the movement kinematics (reciprocation), alloy (M-Wire), and tip size (8), which may account for the similar results found herein and in other studies $(4,7)$.

An original premise of the current study is that larger apical preparations would be able to affect the canal surface area touched by the instruments, which was statistically confirmed, leading to the rejection of the third hypothesis. Larger apical preparations have been related to the improvement of disinfection and cleaning procedures $(4,23,24)$, as this approach significantly boosts the irrigant flushing in the apical region, reducing the bacterial load in the canal system $(5,25)$. In fact, this cannot be regarded as a surprising result, as a previous micro-CT study has already demonstrated an improvement of the shaping ability when larger apical preparations were performed (18).

Undoubtedly, the main focus of the present study was on the overall quality of root canal preparation by reciprocating single-file systems, which is a topic of interest of current scientific and clinical research $(4,7,8,26)$. A

$\vec{s}$ percentage of untouched canal area ranging from $27.68 \%$ $\Xi$ to $60.77 \%$ underlines the less-than-ideal shaping ability of the available armamentarium to prepare the root canal space. Consequently, these findings emphasize the key role of irrigation and intracanal dressing materials in an attempt to compensate the suboptimal status of the mechanical debridement, acting throughout the untouched canal areas $(1,5)$.

In these experimental conditions, reciprocating and rotary systems showed similar shaping ability regardless the percentage of non-instrumented root canal walls; however, all systems produced a suboptimal mechanical preparation of the mesial canals of mandibular molars. Larger final apical sizes showed a convincing positive effect on the shaping ability of the tested systems.

\section{Resumo}

0 objetivo deste estudo foi comparar a porcentagem de área nãoinstrumentada de canais radiculares preparados com diferentes ampliações utilizando sistemas reciprocantes de lima única (Reciproc e WaveOne) e um sistema rotatório convencional de múltiplas limas (BioRaCe) usando a análise da micro tomografia computadorizada. Trinta raizes mesiais de molares inferiores com curvatura moderada $\left(10^{\circ}\right.$ a $\left.20^{\circ}\right)$ apresentando a configuração classe II de Vertucci e semelhança de volume do canal foram selecionadas e escaneadas em uma resolução isotrópica de 14,16 $\mu \mathrm{m}$. A amostra foi dividida em 3 grupos $(\mathrm{n}=10)$ de acordo com o sistema utilizado para a preparação do canal radicular: grupo Reciproc, grupo WaveOne e grupo BioRaCe. Segundo e terceiro escaneamentos foram realizados após os canais serem preparados com instrumentos tamanhos 25 e 40, respectivamente. As imagens registradas de voxels da área de superficie dos canais, antes e após o preparo, foram examinadas desde o nível da furca até o ápice para quantificar a superfície não instrumentada.
Os dados foram comparados estatisticamente através de GLM para medidas repetidas com um nivel de significância de 5\%. Os sistemas de instrumentação não influenciaram o percentual de superfícies não tocadas dos canais radiculares $(p=0,690)$, enquanto que uma redução significativa no percentual de voxels estáticos foi observada após o alargamento do canal radicular $(p=0,010)$ em todos os grupos $(p=0,507)$. Nenhum dos sistemas foi capaz de preparar toda a área de superfície do canal mesial dos molares inferiores. 0 aumento do tamanho final apical resultou num efeito positivo significativo sobre a capacidade de modelar dos sistemas testados.

\section{References}

1. De-Deus G, Barino B, Zamolyi RQ, Souza E, Fonseca A Jr., Fidel S, et al.. Suboptimal debridement quality produced by the single-file F2 ProTaper technique in oval-shaped canals. J Endod 2010;36:18971900.

2. Yared G. Canal preparation using only one Ni-Ti rotary instrument: preliminary observations. Int Endod J 2008;41:339-344.

3. De-Deus G, Arruda TE, Souza EM, Neves A, Magalhães K, Thuanne E, et al.. The ability of the Reciproc R25 instrument to reach the full root canal working length without a glide path. Int Endod J 2013;46:993998.

4. Bürklein S, Hinschitza K, Dammaschke T, Schäfer E. Shaping ability and cleaning effectiveness of two single-file systems in severely curved root canals of extracted teeth: Reciproc and WaveOne versus Mtwo and ProTaper. Int Endod J 2012;45:449-461.

5. Siqueira Jr. JF, Alves FRF, Versiani MA, Rôças IN, Almeida BM, Neves MA, et al.. Correlative bacteriologic and micro-computed tomographic analysis of mandibular molar mesial canals prepared by Self-Adjusting File, Reciproc and Twisted File systems. J Endod 2013;39:1044-1050.

6. Stern S, Patel S, Foschi F, Sherriff M, Mannocci F. Changes in centring and shaping ability using three nickel-titanium instrumentation techniques analysed by micro-computed tomography $(\mu \mathrm{CT})$. Int Endod J 2012;45:514-523.

7. Versiani MA, Leoni GB, Steier L, De-Deus G, Tassani S, Pécora JD, et al.. Micro-computed tomography study of oval-shaped canals prepared with the self-adjusting file, Reciproc, WaveOne and ProTaper Universal systems. J Endod 2013;39:1060-1066.

8. You SY, Kim HC, Bae KS, Baek SH, Kum KY, Lee W. Shaping ability of reciprocating motion in curved root canals: a comparative study with micro-computed tomography. J Endod 2011;37:1296-1300.

9. Bürklein $S$, Schäfer E. Apically extruded debris with reciprocating single-file and full-sequence rotary instrumentation systems. J Endod 2012;38:850-852.

10. Robinson JP, Lumley PJ, Cooper PR, Grover LM, Walmsley AD. Reciprocating root canal technique induces greater debris accumulation than a continuous rotary technique as assessed by 3-dimensional micro-computed tomography. J Endod 2013;39:10671070.

11. Rhodes JS, Ford TR, Lynch JA, Liepins PJ, Curtis RV. Micro-computed tomography: a new tool for experimental endodontology. Int Endod J 1999;32:165-170.

12. Ordinola-Zapata $\mathrm{R}$, Bramante $\mathrm{CM}$, Villas-Boas $\mathrm{MH}$, Cavenago $\mathrm{BC}$, Duarte $\mathrm{MH}$, Versiani MA. Morphologic micro-computed tomography analysis of mandibular premolars with three root canals. J Endod 2013;39:11301135.

13. Versiani MA, Pécora JD, Sousa-Neto MD. The anatomy of two-rooted mandibular canines determined using micro-computed tomography. Int Endod J 2011;44:682-687.

14. Versiani MA, Pécora JD, Sousa-Neto MD. Root and root canal morphology of four-rooted maxillary second molars: a microcomputed tomography study. J Endod 2012;38:977-982.

15. Versiani MA, Pécora JD, Sousa-Neto MD. Microcomputed tomography analysis of the root canal morphology of single-rooted mandibular canines. Int Endod J 2013;46:800-807.

16. Paqué $F$, Balmer $M$, Attin $T$, Peters OA. Preparation of oval-shaped root canals in mandibular molars using nickel-titanium rotary instruments: 
a micro-computed tomography study. J Endod 2010;36:703-707.

17. Paqué $F$, Peters $\mathrm{OA}$. Micro-computed tomography evaluation of the preparation of long oval root canals in mandibular molars with the self-adjusting file. J Endod 2011;37:517-521.

18. Paqué $F$, Ganahl D, Peters OA. Effects of root canal preparation on apical geometry assessed by micro-computed tomography. J Endod 2009;35:1056-1059.

19. Schneider SW. A comparison of canal preparations in straight and curved root canals. Oral Surg Oral Med Oral Pathol 1971;32:271-275.

20. Vertucci FJ. Root canal anatomy of the human permanent teeth. Oral Surg Oral Med Oral Pathol 1984;58:589-599.

21. Paqué $F$, Zehnder $M$, De-Deus $G$. Microtomography-based comparison of reciprocating single-file F2 ProTaper technique versus rotary full sequence. J Endod 2011;37:1394-1397.

22. De-Deus G, Vieira VTL, Silva EJN, Lopes H, Elias CN, Moreira EJ. Bending resistance and dynamic and static cyclic fatigue life of Reciproc and WaveOne large instruments. J Endod 2014;40:575-579.
23. Card SJ, Sigurdsson A, Ørstavik D, Trope M. The effectiveness of increased apical enlargement in reducing intracanal bacteria. J Endod 2002;28:779-783.

24. Fornari VJ, Silva-Sousa YT, Vanni JR, Pécora JD, Versiani MA, Sousa-Neto MD. Histological evaluation of the effectiveness of increased apical enlargement for cleaning the apical third of curved canals. Int Endod J 2010;43:988-994

25. Hülsmann M, Peters OA, Dummer PMH. Mechanical preparation of root canals: shaping goals, techniques and means. Endod Topics 2005; 10:30-76.

26. Bürklein S, Benten S, Schäfer E. Quantitative evaluation of apically extruded debris with different single-file systems: Reciproc, F360 and OneShape versus Mtwo. Int Endod J 2014;47:405-409.

Received March 2, 2015

Accepted August 24, 2015 